\title{
Risk Management In The Supply Chain: Characterization And Empirical Analysis
}

Lhoussaine Ouabouch, Université Ibn Zohr, ERETTLOG, Morocco Gilles Paché, Aix-Marseille Université, CRET-LOG, France

\begin{abstract}
Along any supply chain, a multitude of more or less critical incidents may prevent a company from obtaining the expected level of logistical performance. Knowing how to anticipate and manage supply chain risks is therefore an important approach to maintain a competitive advantage. The target of this article is to evaluate the impact of the risks in relation to the functioning of a supply chain on its logistical performance. For such needs, a survey was administered with 158 Moroccan manufacturers. The data collected allows to successively measure the impacts of the risks linked to the management of the upstream supply chain, of operational risks and risks linked to the management of the downstream supply chain on the logistical performance.
\end{abstract}

Keywords: Morocco; Logistical Performance; Manufacturing Industry; Risk Management; Supply Chain

\section{INTRODUCTION}

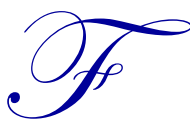

or the past twenty-five years, the interest for the functioning of supply chains has not run out. It has given rise to impressive literature in many countries, in particular, in Europe, North America and more recently, Asia and Australia. For example, the Google Scholar database showed over 1.9 million results in September 2013 for the expression "supply chain management," and more than half of the results are dated after 2000. It is, therefore, a major theme in the economic environment where shortening of time-to-market, the growth of consumer service and the reduction of logistical costs have become key factors of success for companies. Summarily put, we can define the supply chain management as the management of interconnected or interlinked node businesses involved in the provision of product and service packages required by the end customers in a supply chain (Harland, 1996). A supply chain is considered here as a system composed of interdependent and upgradeable elements (production facilities, distribution centers, transport assets, etc.), for which the disruption of an element can negatively influence the performance of the entire supply chain (Tummala \& Schoenherr, 2011; Waters, 2011; Lavastre, Gunasekaran, \& Spalanzani, 2012).

This possible disruption, for example, a rupture in the functioning of production facilities, generates an important risk, the fact of being unable to satisfy a customer in time. In view of the literature of risk management within the supply chains, a few definitions of the notion of risk are suggested, amongst others, by Zsidisin (2003), Rao \& Goldsby (2009) or Tang \& Nurmaya Musa (2010). In this article, the concept of risks linked to the functioning of the supply chain will designate the little foreseeable incidents or events, affecting or coming from one or many supply chain members that can negatively influence the fulfillment of the objectives of each company and harm their performance. The mission of supply chain risk management is to offer tools allowing an evaluation and an optimal follow-up of risks (Lavastre, Gunasekaran, \& Spalanzani, 2012). The question is now essential because, as pointed out in many research studies, companies are confronted with the control of an increasing number of risks that affect their capacity to serve clients efficiently (Wagner \& Bode, 2008). In the end, it is the companies that best reduce uncertainty in the supply chain that are more likely to produce performance. Hence the importance of producing a model for the supply chains taking robustness and resilience into consideration - as a critical component of supply chain risk management (Ponis \& Koronis, 2012) - depending on the impact of the disruption risks, but also on their occurrence, their detectability and their recovery (Bilsel \& Ravindram, 2012; Colicchia \& Strozzi, 2012). 
Schoenherr et al. (2012) underlines that the risk theme is a field of investigation of utmost importance in the context of supply chain management. However, even though research has tried to evaluate the influence of the risk on the efficient functioning of the supply chain, for example, by analyzing the risk identification, the risk assessment and the risk mitigation (Kern et al., 2012), the literature does not yet bring sufficient answers on the influence of risks on the logistical performance. Based on an empirical research driven in Morocco, the article aims at filling that gap while making a few clarifications on the relationship between risks and performance of supply chains. The question is as follows: to what extent do these potential risks linked to the functioning of supply chain influence the logistical performance, individually (each company), then globally (relationships between companies)? In order to answer this question, the first part of this article is dedicated to the presentation of a typology of risks related to logistics chains. The second part covers the research methodology. The validity and reliability of scales of measurement are argued in the third part. The results of the empirical study are presented in the fourth section, which are then discussed in the conclusive fifth section.

\section{LITERATURE REVIEW AND HYPOTHESES}

In the process of risks analysis, the identification step is often considered as essential. The literature enables the identification of a set of risk factors linked to the functioning of supply chains, and that could harm its level of logistical performance. Through logistical performance, we mean the capacity to ensure the satisfaction of the client by delivering good quality products, in the right quantity, at the right time, in the right place by consuming fewer resources. Among the typology of existing risks, we have adopted the classification within three large families developed by Davis (1993). They successively analyze the risks associated to the management of the upstream supply chain (relationships with the suppliers), the operational risks (within the company), and the risks linked to the management of the downstream supply chain (relationships with the customers). Pfohl, Köhler, \& Thomas' (2010) vision is relatively similar, they refer to risks within a focal firm and risks outside of this company and within the supply chain. The authors add the risks outside of the supply chain that affect the focal firm, natural catastrophes or wars for example, that we will not address in this article. A recent synthesis is suggested by Behnezhad, Connett, \& Nair (2013).

\section{Risks Linked to the Management of the Upstream Supply Chain}

Companies are exposed to numerous risks associated to the upstream side of logistical chains. The supply risks can be a result of the purchasing, the suppliers, the relationships with the latter and the supply networks. Zsidisin (2003) underlines that the supply risks are perceived from three different sources: (1) products and services bought; (2) the nature and the number of suppliers; and (3) the market in which the supply operates. The uncertainty linked to the suppliers and to its market in which the supplying operates is confirmed by Ziegenbein \& Nienhaus (2004), as well as Trkman \& McCormack (2009) and Manuj (2013). A market including a small number of alternating suppliers, and subject to strong capacity constraints, unstable price and a volatile exchange rate, generates a high supply risk according to Waters (2011). The parameters such as the delivery time, the quality and the price proposed by the suppliers can also be the reason of unpredictable events, for example, further to a strike action or to production problems. Finally, the supplier's flexibility problems towards erratic evolutions of the customers' demand can impede the functioning of a supply chain, with the lack of components delivered in sufficient quality and at the right time. The set of risks linked to the management of the upstream supply chain could therefore harm the logistical performance in terms of respect of deadlines, or reactivity when dealing with hazards and logistical cost reduction. Hence, the first hypothesis:

H1: The risks of failure in the upstream supply chain have a negative impact on the logistical performance.

\section{Operational Risks}

Given that an operational risk is associated with the execution of a company's business functions (Borghesi \& Gaudenzi, 2013), we consider that many possible sources of operational risks exist within the logistical process of a company. Jüttner, Peck, \& Christopher (2003) signal the sometimes dramatic impact of the radical modification of these processes or of their simple restructuring to reduce costs of labor. The misunderstanding by the personnel of the new processes implemented, the disagreement with the necessary restructuring, or the negative consequences that may result (for example, work intensification) can lead to a loss of efficiency that will impact the logistical 
performance. We can therefore imagine that the strain within the company may result in the decrease of the implication of employees, which will finally lead to the non-achievement of the objectives sought through the modification of the process (Wagner \& Bode, 2008). Here, one finds questions consistently present in the analysis of the founding of the organizational effectiveness (Oghojafor, Muo, \& Aduloju, 2012). Besides, the unavailability of material or human resources and/or the absence of the information necessary to the decision making can harm the efficiency of the company; as Hollstein \& Himpel (2013, p. 22) noted "in order to increase resilience of a supply chain, it is essential that all supply chain partners have access to relevant information." The potential failures at the level of the infrastructure, for example, concerning the maintenance of the production tool, also risk including delays in deliveries and quantitative or qualitative defects that will disturb the supply chain (Narasimhan \& Talluri, 2009; Tang \& Nurmaya Musa, 2010). Hence, the second hypothesis:

H2: The operational risks negatively influence the logistical performance.

\section{Risks Linked to the Management of the Dowstream Supply Chain}

A last category of risks must be taken into account: those that essentially arise from the disturbance relative to the organisation of the dowstream supply chain, in the relationship between the manufacturer and its clients (Jüttner, 2005). Two aspects should be priviledged. On the one hand, the volatility of the market making the behavior of its customers often very unpredictable, on the other hand, the stockouts in the delivery of products to the customer, in particular at the level of transport activities (Lai, Ngai, \& Chang, 2004). Finally, incorrect predictions of the customer's needs induce a risk of insatisfaction, that may translate into a deferral of its purchases towards substitute products of the same manufacturer, or even a purchase from a competing manufacturer (Gratacap \& Gaultier-Gaillard, 2006). The problem will then be to find the perfect balance between the anticipation of the demand through the creation of costly stocks, and a just-in-time functionning of the supply chain, that could increase the risk of stockouts. It is the central trade-off in logistical management, in cost and service quality (Paché, 2014). Based on the case study led with North America's leading retailer of food, supplies, accessories, pets and professional services for the lifetime needs of pets, Oke \& Gopalakrishnan (2009) underline how the retail supply chains have become sensitive to disruption phenomenon that directly threaten their profitability. Hense, the third hypothesis:

H3: The risks of failure in the downstream supply chain have a negative impact on the logistical performance.

The literature review shows, as Belin-Munier (2008) underlines, that the analysis of the logistical performance within the supply chains should be paired with the analysis of the risk as soon as the companies are confronted with an uncertain environment. The disturbance of physical and/or information flows between the supply chain members can create undesirable effects, such as the unavailability problems of products, delays in deliveries or lack of reactivity of the supply chain. As supported in particular by Zsidisin et al. (2008) and Wagner \& Bode (2008), the companies that are the most affected by the failures of the supply chain can be the least likely to produce logistical performance with their partners. Hence, the interest of studying how the supplier integration, the internal integration and the customer integration can impact the logistical performance by decreasing the risks (Zhao et al., 2013). Figure 1 summarizes the research model finally retained in the article.

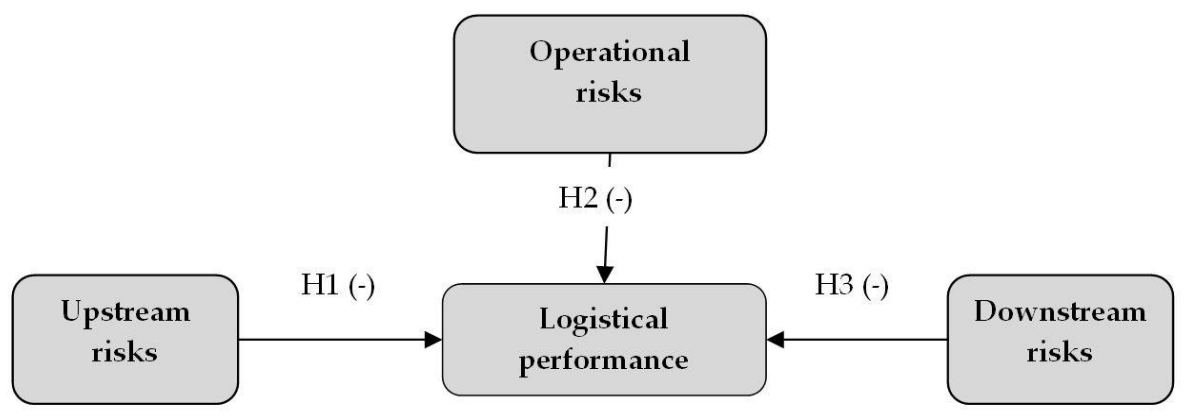

Figure 1: Research Model 


\section{METHODOLOGY}

Our target is to contribute to the enrichment of the corpus on the supply chain risk management, which great vivacity for the past ten years is underlined by Sodhi, Son, \& Tang (2012). The main idea is to study the question in a singular cultural context, the one of an emerging country with a strong development, by adopting a hypothetico-deductive approach. Before measuring the validity and the reliability of scales of measurement, then experimentally testing the research model by empirically verifying the three hypotheses put forward, the methodology needs to be a double plan survey and the choice of the research field.

\section{Scales of Measurement and Survey}

To measure the construct Risks Linked to the Management of the Upstream Supply Chain, six items were used, regarding economic conditions on the supply market and the failures specific to the suppliers. The construct Operational Risks are evaluated thanks to three items related to potential infrastructure failures, whether it is for technical, human or logistical reasons. As for the construct Risks Linked to Management of the Downstream Supply Chain, it is measured through four items linked to the variability of the downstream market and to the risks associated to the sales relationship. Finally, to measure the dependent variable, that is the Logistical Performance within the Supply Chain, we used the four item scale elaborated by Rodrigues, Stank, \& Lynch (2004), which is focused on the downstream efficiency of the supply chain.

Our research being of a quantitative type, the tools recommended for the data gathering is the survey. The latter is composed of four axes aiming at clarifying the importance of the effects of the potential risks in the functioning of supply chains and their influence on the logistical performance. With the intermediary of closed questions, and thanks to the 5-point Likert scales ranging from No Effect (=1) to Strong Effect (= 5), we asked people to evaluate different statements related to the negative effects of a series of possible incidents for their company. The survey is based on items which validity has been, for a majority, demonstrated through anterior empirical studies, even though the theme dealt with in the article remains emerging (Rodrigues, Stank, \& Lynch, 2004; Vanany, Zailani, \& Pujawan, 2009). With the exception of the dependent variable Logistical Performance within the Supply Chain, the formalized scales for the measurement of other constructs are therefore not sufficiently developed yet. The origins of the scales of measurement are presented in Table 1.

Table 1: Origin of Scales of Measurement of Constructs

\begin{tabular}{lc}
\hline \multicolumn{1}{c}{ Variables } & Origin of the Scale of Measurement \\
\hline & Vorst \& Beulens (2002) \\
Risks Linked to the Management of the Upstream Supply Chain & Zsidisin et al. (2008) \\
& Wagner \& Bode (2008) \\
Thun \& Thoenig (2011)
\end{tabular}

\section{Research Field and Data Collection}

The study looks into several industries in Morocco. This country was chosen because of its central position in the European and African markets. According to the Logistics Performance Index (LPI) of the World Bank, Morocco moved from the $94^{\text {th }}$ place in the world market in 2007 into the $50^{\text {th }}$ in 2012, and it currently represents $33 \%$ of multinational firms' direct investments that have turned towards North Africa. Finally, the free trade agreements concluded with the United States of America, the European Union, Turkey, and more recently, Canada, underline its rapid integration in global supply chains on the scale of the planet. In terms of corporate strategy, for the past couple of years, Moroccan decisions makers have become more aware of the stakes of supply chain management, while the Authorities make an unprecedented effort to improve road, rail and port infrastructures. This shows that the logistical performance is a major concern both in the private and public sphere (Ouazzani Chahdi, 2009). 
The article pays particular attention to the agri-food, car, chemical and para-chemical, textile, electrical and electronics industries, given their importance in the national economy (Ministère Marocain de l'Industrie, du Commerce et des Nouvelles Technologies, 2012). 450 surveys were sent out by e-mail between November 2012 and January 2013. The key target group in companies is managers involved in duties of the supply chain in a broad sense (supply chain managers, logistics managers, procurement managers, operations managers). They are better positioned to answer the survey, because of the transverse character of their duties within the company. With a total of 165 surveys received, there was a $36.6 \%$ answer rate. Given the time dedicated to data collecting, as well as the targeted profiles, this rate can be considered as very high, and clearly higher than many researches lead on the supply chain management in Morocco (Abbad, 2008; Bensalem, 2013). During the analysis, seven surveys were not used because of the incoherence of the answers or because of a large number of missing answers. Finally, 158 surveys were used for the data analysis, and the statistical processing was done with the SPSS software (Version 20.0).

The data collecting results in the constitution of a heterogeneous sample, covering a large set of industries, and diverse company sizes. The Appendices A and B summarize the major characteristics of the companies having answered the survey. Among these companies, over $60 \%$ have more than 100 employees, and make an annual turnover of over 50 million Dhs (approximately 5 million euros, at the rate of exchange of September 2013). The companies which annual turnover exceed 600 million Dhs represent over $30 \%$ of the sample, this makes our results significant for the more internationalized industries and integrate in global supply chains. Finally, the agri-food industry represents $27 \%$ of the sample; this also corresponds perfectly to the structure of the Moroccan industry.

\section{VALIDITY AND RELIABILITY SCALES OF MEASUREMENT}

In order to validate the structure of causal relationships (risks and logistical performance within the supply chain), defined in the research model, two types of analyses were led: the descriptive analysis, which constitutes in the purification of the scales of measurement, and the explanatory analysis, which is based on the realization of correlative tests and models of comparison of means. The results of the descriptive analysis of the variables include the tests of validity of the construct (converging validity and discriminant validity) and the tests of reliability of scales of measurement. The items, whose indicator of validity or reliability is inferior to values tolerated in psychometric studies, have been removed. A principal component analysis (PCA) was done with SPSS. The results of the test of discriminant validity - after a Varimax rotation with a Kaiser normalization having converged in five iterations - are presented in Table 2.

Table 2: Results of the Test of Discriminant Validity for the Whole Set of Variables of the Model (Matrix of Components after Rotation)

\begin{tabular}{|c|c|c|c|c|}
\hline \multirow{2}{*}{ Items } & \multicolumn{4}{|c|}{ Component } \\
\hline & 1 & 2 & 3 & 4 \\
\hline UpstreamRisk1 & .675 & .245 & -.032 & .365 \\
\hline UpstreamRisk2 & .832 & .073 & .007 & .168 \\
\hline UpstreamRisk3 & .785 & .272 & .016 & .157 \\
\hline UpstreamRisk4 & .757 & .192 & -.052 & .226 \\
\hline UpstreamRisk5 & .727 & .281 & -.024 & .223 \\
\hline UpstreamRisk6 & .649 & .421 & -.036 & .151 \\
\hline OperationalRisk1 & .411 & .737 & -.081 & .195 \\
\hline OperationalRisk2 & .313 & .846 & -.025 & .155 \\
\hline OperationalRisk3 & .220 & .846 & -.056 & .167 \\
\hline DownstreamRisk1 & .289 & .172 & .583 & -.061 \\
\hline DownstreamRisk2 & .171 & .041 & .773 & -.063 \\
\hline DownstreamRisk3 & .303 & .293 & .578 & -.013 \\
\hline DownstreamRisk4 & .230 & .220 & .734 & -.015 \\
\hline Performance1 & .052 & -.088 & .131 & .760 \\
\hline Performance2 & -.022 & -.078 & -.063 & .835 \\
\hline Performance 3 & -.089 & .083 & -.086 & .838 \\
\hline Performance4 & -.018 & -.041 & -.102 & .783 \\
\hline
\end{tabular}


The set of items is represented in their respective factors. The representative qualities are all superior to the tolerance threshold of 0.40 (Evrard, Pras, \& Roux, 2009), and vary between 0.50 and 0.92. Finally, the factors' extracted eigenvalues are largely superior to 1 and give explained variance percentages from $65.0 \%$ to $81.5 \%$. The level of the structural coefficient of the PCA was set at 0.70 to extract only the factors having a strong converging validity in the meaning of Hair et al. (2009). The totality of the items retained shows a strong contribution to the constitutions of factors, varying between 0.75 and 0.92 . The analysis of correlation coefficients shows independent relationships between scales, providing evidence of the unidimensionality of the constructs. Regarding the reliability of the internal coherence of the scales of measurement, it is verified on the basis that the Cronbach test is superior to 0.70 (Evrard, Pras, \& Roux, 2009), and exceptionally to 0.6 for new constructs (Nunnally \& Bernstein, 1994). The items' factorial scores, the explained variance percentage per factor and the values of Cronbach's Alpha are presented in Table 3. Please note that the rotation method used is also of Varimax-type with a Kaiser normalization. The descriptive analysis confirms the validity of the constructs and the reliability of the recommended scales of measurement. The validated constructs enable the examination of the model's causality relationship and test three hypotheses.

Table 3: Recap of the Validity and Reliability of the Scales of Measurement

$\begin{array}{ccc}\begin{array}{c}\text { Structural Coefficient } \\ \text { of the PCA }\end{array} & \begin{array}{c}\text { Extracted Variance } \\ (>51 \%)\end{array} & \begin{array}{c}\text { Cronbach's } \alpha \\ (>0.7)\end{array}\end{array}$

To what extent has your company suffered, in the last three years, from the negative effects caused by potential incidents hereunder? For each element, please tick the box which corresponds best to your situation, from 1 (no effect) to 5 (strong effect).

\begin{tabular}{|c|c|c|c|}
\hline \multicolumn{4}{|c|}{ Risks Linked to the Management of the Upstream Supply Chain (7 items) } \\
\hline $\begin{array}{l}\text { UpsRisk1: Failure in suppliers' logistical performance } \\
\text { (delay, failure to comply with delivery schedule, etc.) }\end{array}$ & 0.830 & \multirow{6}{*}{$66.0 \%$} & \multirow{6}{*}{0.905} \\
\hline UpsRisk2: Suppliers' wrong interpretation of your needs & 0.821 & & \\
\hline $\begin{array}{l}\text { UpsRisk3: Suppliers' inability to answer the important } \\
\text { increase in order volumes }\end{array}$ & 0.800 & & \\
\hline UpsRisk4: Product shortage at the level of the supply market & 0.799 & & \\
\hline $\begin{array}{l}\text { UpsRisk5: Bottlenecks or blockage at the level of supply } \\
\text { markets }\end{array}$ & 0.797 & & \\
\hline UpsRisk6: Unplanned shutdown of key supplier's production & 0.790 & & \\
\hline \multicolumn{4}{|l|}{ Operational Risks (3 items) } \\
\hline $\begin{array}{l}\text { OpRisk1: Stop or disruption of your own production units } \\
\text { following local incidents (strike, fire, etc.) }\end{array}$ & 0.922 & \multirow[t]{3}{*}{$81.5 \%$} & \multirow[t]{3}{*}{0.886} \\
\hline $\begin{array}{l}\text { OpRisk2: Stop or disruption of your own production units } \\
\text { following technical problems }\end{array}$ & 0.896 & & \\
\hline $\begin{array}{l}\text { OpRisk3: Stop or disruption of computer infrastructures } \\
\text { (virus propagation, software errors, etc.) }\end{array}$ & 0.891 & & \\
\hline \multicolumn{4}{|c|}{ Risks Linked to the Management of the Downstream Supply Chain (4 items) } \\
\hline $\begin{array}{l}\text { DownRisk1: Insufficient or incorrect information } \\
\text { concerning the orders or the anticipated request of the } \\
\text { clients }\end{array}$ & 0.869 & \multirow{4}{*}{$66.7 \%$} & \multirow{4}{*}{0.801} \\
\hline DownRisk2: Random or strongly changing final demand & 0.822 & & \\
\hline DownRisk3: Cancelation of firm orders by the clients & 0.799 & & \\
\hline $\begin{array}{l}\text { DownRisk4: Late payment or absence of payment by the } \\
\text { clients }\end{array}$ & 0.776 & & \\
\hline \multicolumn{4}{|c|}{ Logistical Performance within the Supply Chain (4 items) } \\
\hline \multicolumn{4}{|c|}{$\begin{array}{l}\text { How have the following indicators develop in your company during the past three years? For each element, please tick the box } \\
\text { which correspond to your situation, from }-2 \text { (significantly worsened) to }+2 \text { (significantly improved) }\end{array}$} \\
\hline $\begin{array}{l}\text { Perf1: Delivery reliability: proper execution of clients' } \\
\text { orders (delays, quantity, etc.) }\end{array}$ & 0.841 & \multirow{4}{*}{$65.0 \%$} & \multirow{4}{*}{0.820} \\
\hline $\begin{array}{l}\text { Perf2: Delivery capacity: satisfaction of the client's demand } \\
\text { with the existing resources }\end{array}$ & 0.840 & & \\
\hline $\begin{array}{l}\text { Perf3: Clients' satisfaction: performance of the offer } \\
\text { regarding the clients' expectations }\end{array}$ & 0.788 & & \\
\hline $\begin{array}{l}\text { Perf4: Speed of delivery: time elapsed between the reception } \\
\text { of the order and the client's delivery }\end{array}$ & 0.752 & & \\
\hline
\end{tabular}




\section{RESULTS}

To measure the strength of the relationship between the two concepts risks and logistical performance, we base ourselves on the linear correlation coefficient that helps identify the presence (or on the contrary, the absence) of a relationship between two variables. Table 4 shows the result of the correlation tests. It appears that the logistical performance within the supply chain is negatively and significantly correlated $(\mathrm{p}<0.05)$ with the category of operational risks $(\mathrm{r}=-0.16)$. The other two categories of risks are also negatively correlated with the logistical performance within the supply chain, but with a lower level of significance $(\mathrm{p}<0.1)$. Therefore, the conditions are not present for a regression testing.

Table 4: Correlation between Logistical Performance within the Supply Chain and Risks Categories

\begin{tabular}{|c|c|c|c|c|}
\hline & & $\begin{array}{c}\text { Coefficient of } \\
\text { Determination } r\end{array}$ & Level of Significance & $p$ \\
\hline $\begin{array}{l}\text { Logistical Performance within the } \\
\text { Upstream Risks }\end{array}$ & Supply Chain: & -0.11 & 0,079 & $<0.1$ \\
\hline $\begin{array}{l}\text { Logistical Performance within the } \\
\text { Operational Risks }\end{array}$ & Supply Chain: & -0.16 & 0.022 & $<0.05$ \\
\hline $\begin{array}{l}\text { Logistical Performance within the } \\
\text { Downstream Risks }\end{array}$ & Supply Chain: & -0.13 & 0,056 & $<0.1$ \\
\hline
\end{tabular}

Three ascending levels were identified for each category of risks (inferior, average and superior), by using the dynamic clouds method. The averages of the logistical performance, depending on the ascendance within the risk levels as per category, have then been analyzed. As indicated in Table 5, and in conformity with the correlation results, the average value of the logistical performance is linked to the perceived risk. Companies which have a low level of upstream or operational risks show a logistical performance superior to the average (respectively 3.95 and 3.96). But when the perceived risk increases, the logistical performance becomes inferior to the average (respectively 3.84 and 3.81). This means that moving from a low level of risks to a high level of risks, the average value of logistical performance unavoidably deteriorates for companies. The two Hypotheses $\mathrm{H} 1$ and $\mathrm{H} 2$ are therefore confirmed. However, this is not valid with downstream risk, we have therefore rejected Hypothesis H3.

Table 5: Comparison of the Logistical Performance Averages within the Supply Chain Depending on the Levels of the Three Categories of Risks

\begin{tabular}{lccc}
\hline & Level of Risk & $\begin{array}{c}\text { Headcount per Group } \\
\text { (Sample: 158) }\end{array}$ & $\begin{array}{c}\text { Logistical Performance Average } \\
\text { within the Supply Chain } \\
\text { (Global Average: 3.90) }\end{array}$ \\
\hline \multirow{3}{*}{ Upstream Risks } & Inferior & 68 & 3.95 \\
& Average & 49 & 3.90 \\
& Superior & 41 & 3.84 \\
\hline \multirow{3}{*}{ Operational Risks } & Inferior & 66 & 3.96 \\
& Average & 40 & 3.88 \\
& Superior & 52 & 3.81 \\
\multirow{2}{*}{ Downstream Risks } & Inferior & 64 & 3.82 \\
& Average & 52 & 4.00 \\
\hline
\end{tabular}

\section{DISCUSSION AND CONCLUSIONS}

The article enabled to understand the issues of risks associated to the supply chains and their influence on the logistical performance. The empirical results on an important sample of Moroccan industrial companies confirm that the risks associated with the supply chain negatively influence its logistical performance:

- In the upstream supply chain, the failures originate from the suppliers or procurement market conditions and it negatively impacts the logistical performance. This analysis is in line with Kraljic's (1983) observations which states that companies must evaluate and manage the uncertainties linked to the supplier portfolio in a proactive way in order to protect themselves from potentially expensive dysfunction.

- At the operational level, the risks have a significant effect on the product flow management. They are related to the potential infrastructure failures for technical, human or logistical reasons. As highlighted by 
Jüttner, Peck, \& Christopher (2003) and Wagner \& Bode (2008), the operational risks can lead to a loss in efficiency, as well as an inability to achieve business objectives, which is supported by the answers obtained.

- In the downstream supply chain, the data collected does not confirm the direct negative effects of the risks on the logistical performance. The incidents are related to problems of information asymmetry between the company and its clients, to the imprecision of the forecasts as well as the volatility of the demand. They also originate from the elements associated to the trading relationships as late payment or clients' cancellation of firm orders.

While the third family of risks are worrying for companies, as they can have a visible effect in terms of market loss, the empirical study led with our sample of 158 manufacturers reveals that the influence of operational failures and of failures in the upstream supply chain on the logistical performance are far from negligible. The result is not surprising when analyzing the supply chain in its totality; by underlining the total interdependence between the product's availability for a client to its capacity to make the supply in raw materials and components reliable (Paché, 2014). The challenge for manufacturers therefore consists in the control of incidents originating from the set of interfaces established with their partners, in the upstream and downstream supply chain, not forgetting a perfect coordination of internal logistical processes in the focal company.

On a managerial level, two important conclusions can be drawn from the investigation carried out. In the first place, given that the risks linked to the functioning of the supply chain negatively affect the logistical performance as defined at the beginning of the article, it is capital to integrate the stakes of risk management in the strategic thinking to reduce the potential vulnerability of the company. Secondly, failures have short, mid and longterm impacts that need to be clarified. Hendricks \& Singhal (2005) showed that the stock-outs in supply networks induce lost sales in the short run, as well as loss of global performance in the long run, for example in terms of stock market valuation. Indeed, an unexpected event that disturbs the supply conditions, at any step of the supply chain, can have dramatic consequences on the reputation of a company, to which financial markets could be very sensitive.

The article constitutes a first thought to understand and analyze the risks linked to the functioning of a supply chain in the context of a rapidly growing emerging economy: Morocco. Obviously, efforts must be continued to improve our knowledge of supply chain risk management, by using complementary approaches, in particular based on the study of the legal dimension linked to risks. Future research could also integrate a certain number of moderator variables such as management practices or risk prevention, or control variables like the size and the experience (age) of the company. Furthermore, the contextual characteristics of the supply chain can vary the effects of risks on the logistical performance, for example depending on the complexity of the supply chain in terms of product offer variety (Zsidisin et al., 2008). These effects can be increased by a stronger dependence of the company to its external partners in the upstream and downstream supply chain (Giunipero \& Eltantawy, 2004; Wagner \& Neshat, 2012). From this point of view, a research agenda based on a supply chain typology facing the different risks encountered seems particularly appropriate in the coming years.

\section{AUTHOR INFORMATION}

Lhoussaine Ouabouch is a PhD student in Supply Chain Management at the Université Ibn Zohr and a member of the Equipe de Recherche en Economie du Transport, Technologie de l'Information et Logistique (ERETTLOG), Ecole Nationale de Commerce et de Gestion of Agadir, Morocco. His research fields include logistics management and more precisely risk management in the manufacturing industry from a supply chain perspective. E-mail: 1.ouabouch@uiz.ac.ma

Gilles Paché is a Professor of Retailing and Supply Chain Management at the Aix-Marseille Université, France. He has more than 300 publications in the forms of journal papers, books, edited books, edited proceedings, edited special issues, book chapters, conference papers, and reports. He is Deputy Director of the Centre de Recherche sur le Transport et la Logistique (CRET-LOG) in Aix-en-Provence, and his major interests are network organizations, supply chain management, and retail operations management. E-mail: gilles.pache@univ-amu.fr (Corresponding author) 


\section{REFERENCES}

1. Abbad, H. (2008). L'orientation à long terme dans le canal de distribution: le cas de la relation entre la grande distribution et les PMI agro-alimentaires au Maroc. (Unpublished doctoral dissertation). Université de la Méditerranée (Aix-Marseille II).

2. Behnezhad, A., Connett, B., \& Nair, M. (2013). The evolution of supply chain risk management. Journal of Supply Chain \& Operations Management, 11(1), 77-89.

3. Belin-Munier, C. (2008). Etat de la recherche sur le supply chain management et sa performance: Une revue de la littérature récente. Logistique \& Management, 16(2), 17-30.

4. Bensalem, A. (2013). Développement taxinomique de profils stratégiques d'entreprises manufacturières: une application de la théorie de la contingence aux pratiques supply chain. (Unpublished doctoral dissertation). Aix-Marseille Université.

5. $\quad$ Bilsel, R., \& Ravindran, A. (2012). Modeling disruption risk in supply chain risk management. International Journal of Operations Research \& Information Systems, 3(3), 15-39.

6. Borghesi, A., \& Gaudenzi, B. (2013). Risk management: How to assess, transfer and communicate critical risks. Milan: Springer.

7. Colicchia, C., \& Strozzi, F. (2012). Supply chain risk management: A new methodology for a systematic literature review. Supply Chain Management: An International Journal, 17(4), 403-418.

8. Davis, T. (1993). Effective supply chain management. Sloan Management Review, 13(4), 35-46.

9. $\quad$ Evrard, Y., Pras, B., \& Roux, Y. (2009). Market: Fondements et méthodes des recherches en marketing. (4th ed.). Paris: Dunod.

10. Giunipero, L., \& Eltantawy, R. (2004). Securing the upstream supply chain: A risk management approach. International Journal of Physical Distribution \& Logistics Management, 34(9), 698-713.

11. Gratacap, A., \& Gaultier-Gaillard, S. (2006). Vers une identification des risques intégrée au management stratégique: Le cas de la supply chain. Actes de la $\mathrm{XVI}^{\mathrm{e}}$ Conférence Internationale de Management Stratégique. Annecy, 1-26 (CD-rom).

12. Hair, J., Black, W., Babin, B., \& Anderson, R. (2009). Multivariate data analysis $\left(7^{\text {th }}\right.$ ed.). Upper Saddle River, New Jersey: Prentice Hall.

13. Harland, C. (1966). Supply chain management: Relationships, chains and networks. British Journal of Management, 7(Special Issue), s63-s80.

14. Hendricks, K., \& Singhal, V. (2005). An empirical analysis of the effect of supply chain disruptions on long-run stock price performance and equity risk of the firm. Production \& Operations Management, 14(1), 35-52.

15. Hollstein, C., \& Himpel, F. (2013). Supply chain risk management. LogForum, 9(1), 21-25.

16. Jüttner, U. (2005). Supply chain risk management: understanding the business requirements from a practitioner perspective. International Journal of Logistics Management, 16(1), 120-141.

17. Jüttner, U., Peck, H., \& Christopher, M. (2003). Supply chain risk management: Outlining an agenda for future research. International Journal of Logistics: Research \& Applications, 6(4), 197-210.

18. Kern, D., Moser, R., Hartmann, E., \& Moder, M. (2012). Supply risk management: Model development and empirical analysis. International Journal of Physical Distribution \& Logistics Management, 42(1), $60-$ 82.

19. Kraljic, P. (1983). Purchasing must become supply management. Harvard Business Review, 61(5), 109117.

20. Lai, K.-H., Ngai, E., \& Cheng, T.-C. (2004). An empirical study of supply chain performance in transport logistics. International Journal of Production Economics, 87(3), 321-331.

21. Lavastre, O., Gunasekaran, A., \& Spalanzani, A. (2012). Supply chain risk management in French companies. Decision Support Systems, 52(4), 828-838.

22. Manuj, I. (2013). Risk management in global sourcing. Transportation Journal, 52(1), 80-107.

23. Ministère Marocain de l'Industrie, du Commerce et des Nouvelles Technologies (2012). Industries en chiffres. Rabat. Retrieved June 13, 2014 from http://www.omi.gov.ma

24. Narasimhan, R., \& Talluri, S. (2009). Perspectives on risk management in supply chains. Journal of Operations Management, 27(2), 114-118.

25. Nunnally, J., \& Bernstein, I. (1994). Psychometric theory ( ${ }^{\text {rd }}$ ed.). New York: McGraw-Hill. 
26. Oghojafor, B., Muo, F., \& Aduloju, S. (2012). Organisational effectiveness: Whom and what we do believe? Advances in Management \& Applied Economics, 2(4), 81-108.

27. Oke, A., \& Gopalakrishnan, M. (2009). Managing disruptions in supply chains: A case study of a retail supply chain. International Journal of Production Economics, 118(1), 168-174.

28. Ouazzani Chahdi, F. (2009). La logistique, outil stratégique d'intégration économique dans l'espace euromaghrébin. Rabat: Diwan 3000.

29. Paché, G. (2014). Logistique (gestion). Encyclopadia Universalis. Paris: Club Français du Livre. Retrieved January 27, 2014 from http://www.universalis.fr/encyclopedie/logistique-gestion

30. Pfohl, H., Köhler, H., \& Thomas, D. (2010). State of the art in supply chain risk management research: Empirical and conceptual findings and a roadmap for the implementation in practice. Logistics Research, 2(1), 33-44.

31. Ponis, S., \& Koronis, E. (2012). Supply chain resilience: Definition of concept and its formative elements. Journal of Applied Business Research, 28(5), 921-929.

32. Rao, S., \& Goldsby, T. (2009). Supply chain risks: A review and typology. International Journal of Logistics Management, 20(1), 97-123.

33. Rodrigues, A., Stank, T., \& Lynch, D. (2004). Linking strategy, structure, process, and performance in integrated logistics. Journal of Business Logistics, 25(2), 65-94.

34. Schoenherr, T., Modi, S., Benton, W., Carter, C., Choi, T., Larson, P., Leenders, M., Mabert, V., Narasimhan, R., \& Wagner, S. (2012). Research opportunities in purchasing and supply management. International Journal of Production Research, 50(16), 4556-4579.

35. Sodhi, M., Son, B., \& Tang, C. (2012). Researchers' perspectives on supply chain risk management. Production \& Operations Management, 2l(1), 1-13.

36. Tang, O., \& Nurmaya Musa, S. (2010). Identifying risk issues and research advancements in supply chain risk management. International Journal of Production Economics, 133(1), 25-34.

37. Thun, J.-H., \& Hoenig, D. (2011). An empirical analysis of supply chain risk management in the German automotive industry. International Journal of Production Economics, 131(1), 242-249.

38. Trkman, P., \& McCormack, K. (2009). Supply chain risk in turbulent environments - A conceptual model for managing supply chain network risk. International Journal of Production Economics, 119(2), 247-258.

39. Tummala, R., \& Schoenherr, T. (2011). Assessing and managing risks using the supply chain risk management process (SCRMP). Supply Chain Management: An International Journal, 16(6), 474-483.

40. Vanany, I., Zailani, S., \& Pujawan, N. (2009). Supply chain risk management: literature review and future research. International Journal of Information Systems \& Supply Chain Management, 2(1), 16-33.

41. Vorst, J., \& Beulens, A. (2002). Identifying sources of uncertainty to generate supply chain redesign strategies. International Journal of Physical Distribution \& Logistics Management, 32(6), 409-430.

42. Wagner, S., \& Bode, C. (2008). An empirical examination of supply chain performance along several dimensions of risk. Journal of Business Logistics, 29(1), 307-325.

43. Wagner, S., \& Neshat, N. (2012). A comparison of supply chain vulnerability indices for different categories of firms. International Journal of Production Research, 50(11), 2877-2891.

44. Waters, D. (2011). Supply chain risk management: vulnerability and resilience in logistics $\left(2^{\text {nd }}\right.$ ed.). London: Kogan Page.

45. Zhao, L., Huo, B., Sun, L., \& Zhao, X. (2013). The impact of supply chain risk on supply chain integration and company performance: a global investigation. Supply Chain Management: An International Journal, $18(2), 115-131$.

46. Ziegenbein, A., \& Nienhaus, J. (2004). Coping with supply chain risks on strategic, tactical and operational level. Proceedings of the Global Project and Manufacturing Management Symposium. Siegen, 165-180.

47. Zsidisin, G. (2003). A grounded definition of supply risk. Journal of Purchasing \& Supply Management, 9(5-6), 217-224.

48. Zsidisin, G., Wagner, S., Melnyk, S., Ragatz, G., \& Burns, L. (2008). Supply risk perceptions and practices: an exploratory comparison of German and US supply management professionals. International Journal of Technology, Policy \&Management, 8(4), 401-419. 


\section{APPENDIX A}

Structure of the Sample by Industry

\begin{tabular}{|c|c|c|c|}
\hline Industry & Number & $\%$ & Cumulative \% \\
\hline Agri-food industry & 44 & 27.8 & 27.8 \\
\hline Automotive industry & 16 & 10.1 & 38.0 \\
\hline Aerospace industry & 5 & 3.2 & 41.1 \\
\hline Chemical and pharmaceutical industry & 18 & 11.4 & 52.5 \\
\hline Electrical and electronics industry & 9 & 5.7 & 58.2 \\
\hline Machinery and equipment industry & 4 & 2.5 & 60.8 \\
\hline Textile industry & 13 & 8.2 & 69.0 \\
\hline Construction industry & 18 & 11.4 & 80.4 \\
\hline Rubber and plastics industry & 7 & 4.4 & 84.8 \\
\hline Paper and cardboard industry & 4 & 2.5 & 87.3 \\
\hline Metallurgical industry & 4 & 2.5 & 89.9 \\
\hline Energy and mining & 5 & 3.2 & 93.0 \\
\hline Wood and furniture industry & 7 & 4.4 & 97.5 \\
\hline Other industries & 4 & 2.5 & 100.0 \\
\hline Total & 158 & 100.0 & \\
\hline
\end{tabular}




\section{APPENDIX B}

Salaried Staff and Sales Turnover of the Sample

\begin{tabular}{lcccc}
\hline & & Number & \% & Cumulative \% \\
\hline & $50-99$ & 32 & 20.3 & 20.3 \\
& $100-199$ & 20 & 12.7 & 32.9 \\
Salaried Staff & $200-499$ & 31 & 19.6 & 52.5 \\
& $500-999$ & 27 & 17.1 & 69.6 \\
& $>1,000$ & 20 & 12.7 & 82.3 \\
& Total & 28 & 17.7 & 100.0 \\
\hline & $<10$ million & $\mathbf{1 5 8}$ & 12.0 \\
Annual Sales Turnover & $10-49.9$ million & 19 & 27.8 \\
(in Dhs) & $50-99.9$ million & 25 & 12.0 & 41.1 \\
& $100-399.9$ million & 21 & 15.8 & 57.6 \\
& $400-599.9$ million & 26 & 13.3 & 68.4 \\
& $600-999.9$ million & 17 & 10.5 & 81.0 \\
& $>1,000$ million & 20 & 12.7 & 100.0 \\
\hline
\end{tabular}

